\title{
Red and Black Mulch Color Affects Production of Florida Strawberries
}

\author{
S.J. Locascio, J.P. Gilreath, S. Olson, C.M. Hutchinson, and C.A. Chase \\ Horticultural Sciences Department, GulfCoast Research and Education Center, \\ North Florida Research and Education Center, and Horticultural Sciences \\ Department, University of Florida, Gainesville, Bradenton, and Quincy, FL
}

Additional index words. Fragaria $\times$ ananassa, polyethylene mulch, SMR-red mulch, soil temperature, light reflection, weed growth

\begin{abstract}
Strawberries (Fragaria $\times$ ananassa, Duch) were grown in the annual hill system at four locations in Florida to compare the effects of standard black low density polyethylene (LDPE) mulch and red reflective mulch (SMR-red) on fruit size and production. Marketable fruit size was not affected by mulch color. Early and total marketable fruit yields were not affected by mulch color at Bradenton, but yields were significantly higher at Gainesville with red than black mulch, and were significantly higher with black than red mulch at Quincy and Hastings. Soil temperatures under the black mulch were significantly higher than red mulch at Hastings but significantly higher under red than black mulch at Gainesville. Mean soil temperatures at soil depths of 5 to $25 \mathrm{~cm}$ ranged from 0.2 to 0.4 ${ }^{\circ} \mathrm{C}$ Reflected photosynthetically active radiation values at 25 and $50 \mathrm{~cm}$ above the mulch were higher earlier in the season and decreased as the season progressed. Within a month after transplanting when foliage covered about $10 \%$ of the mulch, reflections were lower and similar at both heights with black mulch than red and were higher at 25 than $50 \mathrm{~cm}$ with red mulch. Data indicate that there was not a consistent advantage of the use of this red mulch over black mulch at four locations in Florida.
\end{abstract}

Strawberries were grown on 2,500 ha in Florida with an on farm value of over $\$ 150$ million in the 1998-99 season with a value of $\$ 60,000$ per ha. The high value of strawberry is dependent on an intense cultural system that includes the use of liming, soil fumigation, polyethylene mulch, fertilizer, drip irrigation, advanced cultivars, foliar pest control, frost protection, and excellent management. Use of black polyethylene mulch is a standard practice in Florida strawberry production since 1962 after its evaluation by Brooks (1959) and Thompson (1959). Adoption and use of polyethylene mulch has been credited with saving the Florida strawberry industry. With the use of mulch and the accompanied increase in soil temperature (Waggoner et al., 1960), reduced nutrient leaching (Locascio and Thompson, 1960), and increased soil moisture (Locascio and Thompson, 1960), strawberry yields have increased substantially over production without mulch. More recently, Decoteau et al., (1988 and 1989) reported that mulch color influenced tomatoplant growth and yield and pepper growth (Decoteau et al.,1990; Kasperbauer and Hunt, 1998) by effects on the upward reflection of light as well as effects on soil temperature. Tomato yields were higher with red than black or white painted polyethylene mulch. Albregts and Chandler (1993) found that strawberry yields were similar with red painted polyethylene mulch and black (unpainted) polyethylene mulch. However, Kasperbauer (2000) reported that strawberry yields were higher with red-

Received for publication 10 Feb. 2004. Accepted for publication 9 Aug. 2004. This research was supported by the Florida Agricultural Experiment Station and approved for publication as Journal series R-09990. selective reflective mulch (SMR) than with black polyethylene mulch. He concluded that the reflected far-red and red light from the red mulch affected phytochrome-mediated allocation of photosynthate that was more directed to developing fruit and resulted in larger fruit than with black mulch. With the combined mulch effect on soil temperature and on reflected light spectrum, SMR mulches may have a different effect than that of mulch painted various colors. Studies reported here were conducted to evaluate the effects of SMR-red mulch and black mulch on strawberry size, yield, and soil temperature at various locations in Florida.

\section{Materials and Methods}

Strawberries were grown in the fall and spring of $2000-01$ at Gainesville $\left(29^{\circ} 72^{\prime} \mathrm{N}\right)$ on a Millhopper fine sand, at Bradenton ( $27^{\circ} 31^{\prime}$ $\mathrm{N})$ on an EauGallie fine sand, at Quincy ( $30^{\circ}$ $58^{\prime} \mathrm{N}$ ) on an Orangeburg fine sandy loam, and at Hastings $\left(29^{\circ} 68^{\prime} \mathrm{N}\right)$ on an Ellzey fine sand. At Gainesville, north-south oriented beds $0.6 \mathrm{~m}$ wide and spaced $1.2 \mathrm{~m}$ apart were fertilized with $56 \mathrm{~N}-25 \mathrm{P}-45 \mathrm{~K}$ (in $\mathrm{kg} \cdot \mathrm{ha}^{-1}$ ) applied broadcast and $67 \%$ methyl bromide (MBr) : $33 \%$ chloropicrin (Pic) was injected at $390 \mathrm{~kg} \cdot \mathrm{ha}^{-1}$ in the bed on 27 Sept. 2000. The above formulation and rate of fumigant were used at Bradenton Quincy and Hastings. Double-wall drip tubing (Chapin Twinwall, Watertown, N.Y.) was placed in the middle of the beds before application of $0.0038-\mathrm{cm}$ black polyethylene mulch or SMR-red mulch (Sonoco Products Co., Hartsville, S.C.). At Hastings, east-west oriented beds $0.6 \mathrm{~m}$ wide and spaced $1.2 \mathrm{~m}$ apart were fertilized with $168 \mathrm{~N}-73 \mathrm{P}-139 \mathrm{~K}$ (in $\mathrm{kg} \cdot \mathrm{ha}^{-1}$ ) was applied preplant and mulched as above on 28 Sept. 2000
Soil temperature was measured at the soil surface $(0.5$ to $1 \mathrm{~cm})$ and at $5-, 10-$, and $25-\mathrm{cm}$ depths in plots mulched with black and red film at Gainesville and Hastings using dataloggers (CR10; Campbell Scientific, Inc., Logan, Utah) from 1 Nov. 2000 to 20 Feb. 2001. Twenty-four 6-m copper-constantan thermocouples were attached to each datalogger via a solid-state multiplexer (AM25T; Campbell Scientific, Inc., Logan, Utah). Dataloggers were programmed to excite thermocouples at 30-min intervals. For each film, three thermocouples were assigned to each depth. Thermocouples were positioned by selecting a spot midway between two strawberry plants in a row and inserting $15 \mathrm{~cm}$ from either edge of the bed, as far as possible from the planting holes. Temperature data for each day were summarized to obtain maximum, minimum and mean temperatures. The effects of mulch color and day of the year on maximum, minimum, and mean soil temperatures were analyzed by location and within each location data were analyzed by soil depth.

At Gainesville and Hastings, bare-root 'Camarosa' strawberry plants (obtained from Simcoe, Ont, Canada and held at $5{ }^{\circ} \mathrm{C}$ before transplanting) were transplanted in double rows on 24 Oct. and 25 Oct. 2000 into plots $1.2 \mathrm{~m}$ wide and $11 \mathrm{~m}$ long with plants spaced $30 \mathrm{~cm}$ apart within and between rows. At all locations, treatments were arranged in a randomized block design with four replications. At Gainesville, additional fertilizer was applied with drip irrigation at $5.6 \mathrm{~N}-0 \mathrm{P}-5.0 \mathrm{~K}$ (in $\mathrm{kg} \cdot \mathrm{ha}^{-1}$ ) for four applications per month for 5 months beginning in the last week of Nov. and ending in the second week of Apr.

At Bradenton, N/S oriented beds $80 \mathrm{~cm}$ wide and spaced $1.5 \mathrm{~m}$ apart were fertilized with $56 \mathrm{~N}-25 \mathrm{P}-47 \mathrm{~K}$ (in $\mathrm{kg} \cdot \mathrm{ha}^{-1}$ ) before application of fumigant and mulch film on 26 Oct. Barerooted 'Camarosa' strawberry plants were

Table 1 . Strawberry early and total yield and fruit size as affected by mulch color at Bradenton, Gainesville, Quincy, and Hastings, Fla., 2000-01?

\begin{tabular}{lccc}
\hline & \multicolumn{3}{c}{ Mulch color } \\
\cline { 2 - 4 } Location & Black & Red & Significance \\
\hline Early yield (flats/ha) & & & \\
Bradenton & 683 & 671 & NS \\
Gainesville & 1134 & 1427 & $*$ \\
Quincy & 1150 & 798 & $*$ \\
Hastings & 1519 & 1253 & NS \\
Mean & 1122 & 1037 & $*$ \\
Total yield (flats/ha) & & & \\
Bradenton & 5774 & 5594 & NS \\
Gainesville & 3336 & 3711 & $*$ \\
Quincy & 4272 & 3482 & $*$ \\
Hastings & 2419 & 1908 & $*$ \\
Mean & 3950 & 3674 & NS \\
Marketable fruit size (g/fruit) & & \\
Bradenton & 18.0 & 18.8 & NS \\
Gainesville & 25.0 & 25.5 & NS \\
Quincy & 19.7 & 20.1 & NS \\
Hastings & NAy & NA & NS \\
Mean & 20.8 & 21.4 & NS \\
\hline
\end{tabular}

${ }^{2}$ Interaction between location and mulch color significant at $P<0.05$.

${ }^{\mathrm{y}} \mathrm{NA}=$ not applicable.

NS, ${ }^{*}$ Mulch color effects were nonsignificant or significant at $P<0.05$, respectively. 
Table 2. Effects of mulch color and soil depth on daily maximum, minimum, and mean soil temperatures $\left({ }^{\circ} \mathrm{C}\right)$ of strawberry bed centers from 1 Nov. 2000 to 20 Feb. 2001 at Gainesville and Hastings, Fla.

\begin{tabular}{|c|c|c|c|c|c|c|}
\hline \multirow{2}{*}{$\begin{array}{l}\text { Mulch } \\
\text { color }\end{array}$} & \multicolumn{3}{|c|}{ Gainesville } & \multicolumn{3}{|c|}{ Hastings } \\
\hline & $\operatorname{Max}$ & Min & Mean & $\operatorname{Max}$ & Min & Mean \\
\hline \multicolumn{7}{|l|}{$0.5 \mathrm{~cm}$ Soil depth } \\
\hline Black & $24.3 \mathrm{a}^{\mathrm{z}}$ & $9.3 \mathrm{a}$ & $15.2 \mathrm{a}$ & $26.1 \mathrm{a}$ & $8.4 \mathrm{a}$ & $14.9 \mathrm{a}$ \\
\hline Red & $24.8 \mathrm{~b}$ & $9.0 \mathrm{~b}$ & $15.2 \mathrm{a}$ & $24.5 \mathrm{~b}$ & $8.4 \mathrm{a}$ & $14.6 \mathrm{a}$ \\
\hline \multicolumn{7}{|l|}{$5 \mathrm{~cm}$ Soil depth } \\
\hline Black & $21.1 \mathrm{a}$ & $11.5 \mathrm{a}$ & $15.6 \mathrm{a}$ & $22.2 \mathrm{a}$ & $10.5 \mathrm{a}$ & $15.2 \mathrm{a}$ \\
\hline Red & $20.8 \mathrm{~b}$ & $11.7 \mathrm{~b}$ & $15.7 \mathrm{~b}$ & $21.2 \mathrm{~b}$ & $10.3 \mathrm{~b}$ & $14.8 \mathrm{~b}$ \\
\hline \multicolumn{7}{|l|}{$10 \mathrm{~cm}$ Soil depth } \\
\hline Black & $19.2 \mathrm{a}^{\mathrm{y}}$ & $12.84 \mathrm{a}$ & $15.7 \mathrm{a}$ & $19.7 \mathrm{a}$ & $12.0 \mathrm{a}$ & $15.4 \mathrm{a}$ \\
\hline Red & $19.6 b^{y}$ & $12.77 \mathrm{~b}$ & $15.8 \mathrm{~b}$ & $19.0 \mathrm{~b}$ & $11.9 \mathrm{~b}$ & $15.0 \mathrm{~b}$ \\
\hline \multicolumn{7}{|l|}{$25 \mathrm{~cm}$ Soil depth } \\
\hline Black & $17.6 \mathrm{a}$ & $14.6 \mathrm{a}$ & $16.1 \mathrm{a}$ & $17.1 \mathrm{a}^{\mathrm{y}}$ & $14.1 \mathrm{a}^{\mathrm{y}}$ & $15.6 \mathrm{a}^{\mathrm{y}}$ \\
\hline Red & $17.8 \mathrm{~b}$ & $14.8 \mathrm{~b}$ & $16.3 \mathrm{~b}$ & $16.7 b^{y}$ & $14.2 b^{y}$ & $15.4 b^{y}$ \\
\hline
\end{tabular}

${ }^{2}$ Mean separation between mulch color at a depth by $\mathrm{F}$ test at $P<0.05$.

${ }^{y}$ Significant interaction at a location between day of the year and mulch color, $P<0.01$.

Table 3. Photosynthetically active radiation (PAR) reflected in strawberry with black and red mulch at Gainesville and Hastings, Fla., 2000-01.

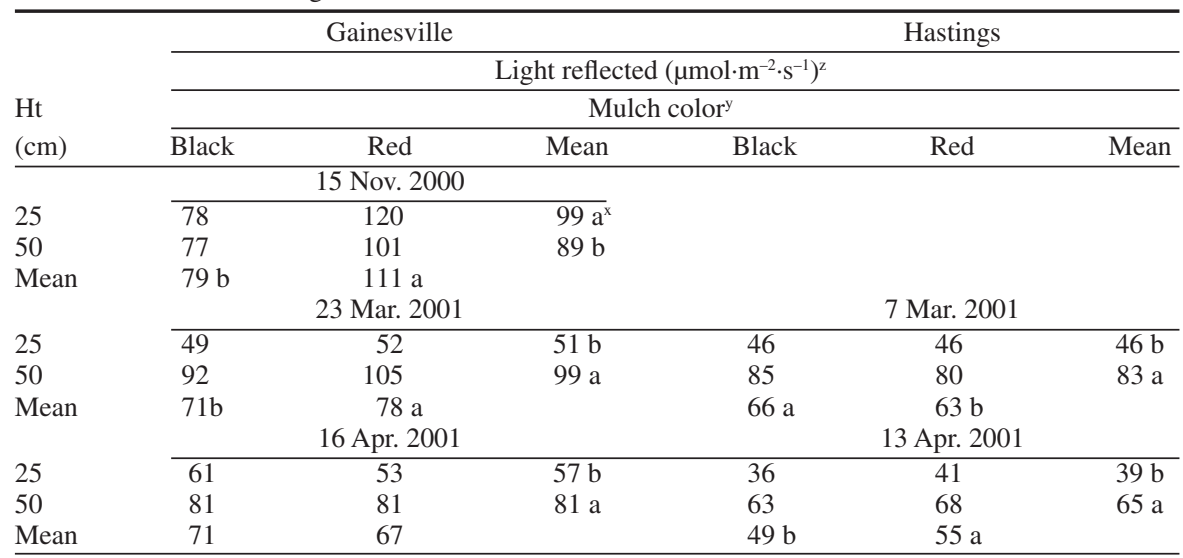

${ }^{2}$ Photosynthetic photos flux density units of quanta (photos) per unit time per unit surface area.

y Interactions between location and mulch color significant $P<0.05$.

${ }^{x}$ Mean separation by Duncans multiple range test $P<0.05$.

Table 4. Weed growth as affected by mulch color in strawberry in early $(9 \mathrm{Jan}$.$) and late (11 Apr.)$ 2001 season at Bradenton, Fla.

\begin{tabular}{llrc}
\hline & \multicolumn{3}{c}{ Weeds/11 $\times 0.6-\mathrm{m}$ bed } \\
\cline { 2 - 4 } & \multicolumn{3}{c}{ Mulch color } \\
\cline { 2 - 4 } Weed & Black & Red & Significance \\
\hline 9 Jan. 2001 & & & $*$ \\
$\quad$ White clover & 0.08 & 2.3 & $*$ \\
11 Apr. 2001 & & & $* *$ \\
Dog fennel & 4.3 & 11.5 & $*$ \\
White clover & 0.7 & 3.2 & $*$ \\
\hline
\end{tabular}

"** Mulch color effects were significant by $\mathrm{F}$ test at $P=0.05$ or 0.01 , respectively.

transplanted on 15 Nov. 2000 in two rows per bed with plants spaced $30 \mathrm{~cm}$ apart within and between rows. Irrigation was supplied through drip tubing (T-Tape; T-Systems International, San Diego, Calif.) installed in the middle of the bed. Additional fertilizer was applied by daily fertigation of 0.6 to $1.2 \mathrm{~kg} \cdot \mathrm{ha}^{-1} \cdot \mathrm{d}^{-1}$ of $\mathrm{N}-0-\mathrm{K}$ from a 6-0-6, depending on the stage of crop growth. At Quincy, north-south oriented beds $90 \mathrm{~cm}$ wide spaced $1.8 \mathrm{~m}$ apart were fertilized with $174 \mathrm{~N}-22 \mathrm{P}-145 \mathrm{~K}$ (in kg.ha ${ }^{-1}$ ). Fumigant and mulches were applied on 20 Aug. with 'Camarosa' plants transplanted on 21 Oct. 2000 as above.

Photosynthetically active radiation (PAR) as photosynthetic photon flux density (PPFD) was measured in quanta (photons) per second
1) were similar with black and red mulch at Bradenton and Hastings, but were higher with red mulch at Gainesville and with black mulch at Quincy. Total marketable fruit yields were similar with black and red mulch at Bradenton, higher with red mulch at Gainesville, and higher with black mulch at Quincy and Hastings. The effect of mulch color on total mean marketable yield at the four locations was not significant. Marketable fruit size was consistent at all locations and was not influenced by mulch color or location. As in this study, reported crop response to mulch color has not been consistent. Kasperbauer (2000) found higher strawberry yields with red than black mulch, but Kaul and Kasperbauer (1992) obtained higher yield of bell pepper with white than red or black mulch and yields were similar with red-painted and black unpainted mulches. Albregts and Chandler (1993) reported that in a three season study with painted mulch, strawberry yields were higher in three seasons with yellow and during two seasons with white than black or red mulch.

Within location there were significant interactions between mulch color and day of the year for maximum soil temperature at 10 $\mathrm{cm}$ depth and maximum, minimum, and mean soil temperatures at $25 \mathrm{~cm}$ depth, indicating that the effect of mulch color on soil temperature varied with the day of the year on which the measurement was taken. Soil temperature was influenced by mulch color differently at Gainesville and Hastings (Table 2). At Gainesville, with north-south oriented beds and drip irrigation, mean soil temperatures from 1 Nov. through 20 Feb. under red mulch were about 0.1 to $0.2^{\circ} \mathrm{C}$ higher at soil depths of 5 to $25 \mathrm{~cm}$ than under black mulch. In contrast, at Hastings with east-west oriented beds with subsurface irrigation where fruit yields were higher with black mulch than red, mean soil temperature values under black mulch were 0.2 to $0.4{ }^{\circ} \mathrm{C}$ higher at 0.5 to $25 \mathrm{~cm}$ depth than under red mulch. Reported differences in soil temperature of red and black mulch are small. Decoteau et al. (1989) found that soil temperatures were about $0.2{ }^{\circ} \mathrm{C}$ warmer under black that red mulch. Albregts and Chandler (1993) found temperatures under black to be as much as 2.0 ${ }^{\circ} \mathrm{C}$ warmer than under red mulch.

Photosynthetically active radiation (PAR) reflected from the black and red mulch after noon was much higher in November when foliage cover was about $10 \%$ (data not shown) than in April when foliage covered $90 \%$ of the bed area (Table 3). Light reflected was higher in March with about $80 \%$ foliage cover than in April At Gainesville in November, light reflection was similar at 25 and $50 \mathrm{~cm}$ above the black mulch, higher with red than black mulch at both heights above the beds, and $20 \%$ higher at 25 than $50 \mathrm{~cm}$ above the red mulch. At Gainesville and Hastings in March, reflected PAR was similar with black and red mulch at $25 \mathrm{~cm}$ and was lower than at $50 \mathrm{~cm}$. At $50 \mathrm{~cm}$, PAR reflections were higher with red mulch at Gainesville but were higher with black mulch at Hastings. With the most dense foliage cover in April, reflections were lower than earlier and less affected by mulch color; 
however, reflections were higher from $50 \mathrm{~cm}$ than from $25 \mathrm{~cm}$ above the mulch.

The number of clover (Melilotus alba) and dogfennel (Eupatorium capillifolium) plants that emerged in strawberry plant holes in the mulch in January and April at Bradenton were significantly higher with red than black mulch (Table 4). Red mulch allowed more light to penetrate the mulch and resulted in more weed growth than through black mulch.

Data from this study indicate that there were no consistent advantages in fruit production or weed control in using SRM-red mulch compared to LDPE black mulch.

\section{Literature Cited}

Albregts, E.E. and C.K. Chandler. 1993. Effect of polyethylene mulch color on the fruit response of strawberry. Soil Crop Sci. Soc. Fla. Proc. 52:40-43.

Brooks, A.N. 1958. Polyethylene film as a mulch for strawberry. Fla. Agr. Expt. Stat. Annu. Rpt. p. 395.

Decoteau, D.R., M.J. Kasperbauer, D.D. Daniels, and P.G. Hunt. 1988. Plastic mulch color affects on reflected light and tomato plant growth. Scientia Hort. 34:169-175.

Decoteau, D.R., M.J. Kasperbauer, and P.G. Hunt. 1989. Mulch surface color affects yield of fresh-market tomatoes. J. Amer. Soc. Hort. Sci.114:216-219.

Decoteau, D.R., M.J. Kasperbauer, and P.G. Hunt. 1990. Bell pepper plant development over mulches of diverse colors. HortScience 25:460-462.

Kaul, K. And M.J. Kasperbauer. 1992. Mulch color effects on reflected light, rhizosphere, temperature, and pepper yield. Ky. Acad. Sci. 53(3-4):109-112.

Kasperbauer, M.J. 2000. Strawberry yield over red versus black plastic mulch. Crop Sci. 40:171-174.

Kasperbauer, M.J. and P.G. Hunt. 1998. Far-red light affects photosynthate allocation and yield of tomato over red mulch. Crop Sci. 38:970-974.

Locascio, S.J. and B.D. Thompson. 1960. Strawberry yield and the soil nutrient levels as affected by fertilizer rate, type of mulch and time of application. Proc. State Hort. Soc. 73:172-179.

Thompson, B.D. 1959. Response of strawberries to mulching with plastic. Proc. Fla. State Hort. Soc. 72:179-185.

Waggoner, P.E., P.M. Miller, and H.C. De Roo. 1960. Plastic mulching: principles and benefits. Conn. Agr. Expt. Sta. Bul. 634. 